\title{
Mineralogical Analysis of Glacial Deposits and Titanium Paleoplacers of the East European Part of Russia
}

\author{
N. Vorobyov and A. Shmakova ${ }^{(\bowtie)}$ \\ Institute of Geology of Komi SC UB RAS, Syktyvkar, Russia \\ alex.sch92@yandex.ru
}

\begin{abstract}
Mineralogical analysis is one of the main methods to determine sources for paleoplacers and location of source glacial provinces. Our studies defined location of source glacier provinces and sources for titanium paleoplacers of the East European Part of Russia.
\end{abstract}

Keywords: Minerals $\cdot$ Reconstruction $\cdot$ Glacial deposits $\cdot$ Titanium paleoplacers

\section{Introduction}

Mineralogical analysis is the most significant method in reconstructing sources paleoplacers and glacial deposits (boulder loams), determining location of source for glacial provinces. The paper presents two objects - glacial deposits of polar and vychegda horizons, Middle Devonian and Middle Triassic titanium paleoplacers.

\section{Results and Discussion}

Quaternary deposits have been studied in two areas of Pechora lowland: in the northeast in the basin of the Padymeytyvys river and northwest in the basin of the Kui river. Titanium paleoplacers were studied at the Kydzarasyu river (Preural Foredeep) and Middle Timan (Pizhma paleoplacer).

Relations between mineral composition of Quaternary deposits and underlying bedrocks are very important. During active exaration activity of the glacier, the underlying rocks controlled composition of boulder loams. The formation of heteroaged horizons of boulder loams is associated with the Northeastern (Paykhoy-Ural-Novaya Zemlya) and Northwestern (Fennoscandinavia) terrigenous-mineralogical source provinces. The rocks of the eastern province are characterized by higher levels of epidote and ilmenite fraction, and the northwestern ones - amphiboles and garnets.

In the basin of the Padymeytyvys river two horizons of boulder loams were drilled. In the lower (Vychegodsky) horizon, epidote (19.9\%) and siderite (21.2\%) dominate in the heavy fraction. In the composition of the heavy fraction of the upper (polar) horizon, pyrite $(22.1 \%)$ and epidote $(20.7 \%)$ have maximum concentrations, siderite content $(11.7 \%)$ and ilmenite $(14.7 \%)$ are high. Pyrite and siderite indicates the relation between the glacier and Triassic and Permian underlying rocks, and ilmenite may be associated with Uralian rocks. 
In the valley of the Kui river one horizon of boulder loam - polar - was drilled. The heavy fraction is represented by amphibole (13.6\%) - garnet (18\%) - epidote $(20.8 \%)$ associations with the increased content of pyrite $(7.7 \%)$. High concentrations of amphiboles (13.6\%) and garnets (18\%) may indicate the relation between the glacier and the rocks of Fennoscandinavia.

The number of amphiboles in boulder loams decreases from west to east and amounts to the first percent. High total contents of pyrite and siderite in the north-east of Pechora lowland are typical of local Mesozoic source province.

Heavy fraction of the paleoplacer at the Kydrasyu river is represented by ilmenite $(45.19 \%)$, epidote $(23.21 \%)$, magnetite $(15.76 \%)$, amphibole $(6.69 \%)$, chrome spinelide $(5.65 \%)$, garnets $(2.06 \%)$. Also zircon, leucoxen, rutile, hematite, kyanite, martite, pumpellyite, staurolite are present $(0.04-0.4 \%)$. The high content of ilmenite indicates the relation between the paleoplacer and igneous rocks. Epidote, garnet, kyanite, staurolite, and pumpellyite found in the heavy fraction are of metamorphic origin. The morphology of zircons is characteristic of minerals formed in igneous rocks of medium composition. The peculiarity of these minerals is their good preservation. This may be due to the nearby source. The mineral composition indicates that the source of minerals was not far from its burial. Titanium minerals and satellite minerals were most likely of magmatic and metamorphic origin.

The mineral composition of titanium placers often contains stable minerals and there are no unstable ones, although both are present in the bedrocks. The main reason is that the paleoplacer formed due to erosion of the weathering crust. An example of a paleoplacer formed that way can be Pizhma paleoplacer (Middle Timan) formed due to erosion and redeposition of weathering crusts on Riphean shales. It's mineral composition in contrast to the paleoplacer at the Kydzarasyu river, is very poor. The main part is represented by leucoxenized ilmenite and leucoxene. Tourmaline, garnet and zircon are found in single units.

\section{Conclusions}

We determined location of the source glacier provinces and sources for the titanium paleoplacers of the East European part of Russia by the mineralogical analysis.

Open Access This chapter is licensed under the terms of the Creative Commons Attribution 4.0 International License (http://creativecommons.org/licenses/by/4.0/), which permits use, sharing, adaptation, distribution and reproduction in any medium or format, as long as you give appropriate credit to the original author(s) and the source, provide a link to the Creative Commons license and indicate if changes were made.

The images or other third party material in this chapter are included in the chapter's Creative Commons license, unless indicated otherwise in a credit line to the material. If material is not included in the chapter's Creative Commons license and your intended use is not permitted by statutory regulation or exceeds the permitted use, you will need to obtain permission directly from the copyright holder.

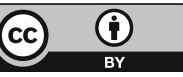

